\title{
The effect of dietary protein on the amino acid supply and threonine metabolism in the pregnant rat
}

\author{
William D. REES ${ }^{a *}$, Susan M. HAY ${ }^{\mathrm{a}}$, Christos ANTIPATIS ${ }^{\mathrm{a}, \mathrm{b}}$ \\ a The Rowett Research Institute, Greenburn Road, Bucksburn, Aberdeen, AB21 9SB, Scotland \\ ${ }^{\mathrm{b}}$ Present address: DSM Nutritional Products Ltd, 4002 Basel, Switzerland
}

(Received 7 June 2005; accepted 24 February 2006)

\begin{abstract}
To characterise the effects of dietary protein content on threonine metabolism during pregnancy, rats were fed diets containing $18 \%$ or $9 \%$ protein and then killed at different stages of gestation. Serum threonine concentrations fell significantly faster in the animals fed the diet containing $9 \%$ protein when compared to those fed the diet containing $18 \%$ protein. On day 4 of gestation the rate of threonine oxidation was higher in maternal liver homogenates prepared from the animals fed the diet containing $18 \%$ protein. The rate of threonine oxidation by liver homogenates fell as gestation proceeded in both diet groups. The activity of threonine dehydrogenase in the maternal liver was unaffected by dietary protein content at all stages of gestation. Serine-threonine dehydratase activity in homogenates of the maternal liver was transiently increased during the early stages of gestation in the animals fed high protein diets but was unchanged in the low protein groups. There was an increase in serine-threonine dehydratase activity in the kidney during the later stages of gestation but this was unaffected by the protein content of the maternal diet. These data show that the changes in free threonine concentrations cannot be accounted for through changes in the oxidation rate and suggest that some other factor influences the unusual metabolism of this amino acid during gestation.
\end{abstract}

threonine dehydratase / threonine dehydrogenase / protein metabolism / pregnancy / foetus / metabolic programming

Abbreviations: SDH, serine/threonine dehydratase; TDH, threonine dehydrogenase; PCA, perchloric acid; TCA, trichloroacetic acid.

\section{INTRODUCTION}

During pregnancy the concentrations of amino acids in the maternal circulation are determined by a combination of factors including the dietary intake, mobilisation of maternal body proteins, maternal protein synthesis and the biosynthetic demands of the foetus. In the rat, there are two separate phases of protein metabolism during pregnancy [1]. During the first two weeks

\footnotetext{
* Corresponding author: wdr@ rri.sari.ac.uk
}

in the anabolic phase, the dam builds up a reserve of protein, particularly in the liver. In the second, catabolic phase of gestation the situation is reversed as the protein reserve built up by the dam during the first phase is mobilised to support the growth of foetal and mammary tissues. Amino acid concentrations reflect these changes in protein metabolism. Previously, we showed that reducing the protein content of casein based semi-synthetic experimental diets from $180 \mathrm{~g} \cdot \mathrm{kg}^{-1}$ to $90 \mathrm{~g} \cdot \mathrm{kg}^{-1}$ 


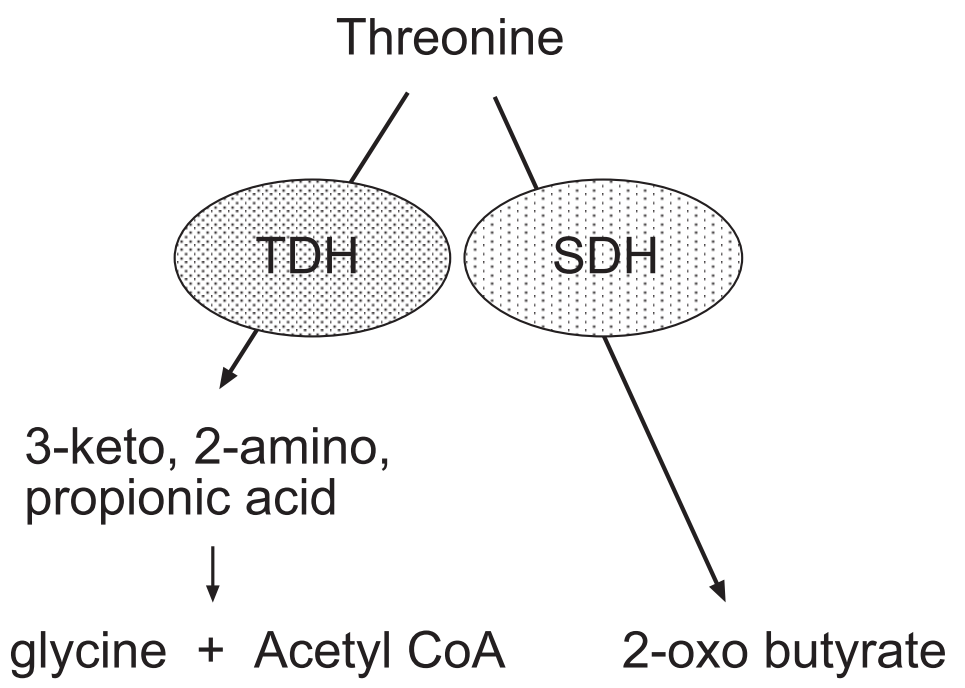

Figure 1. Enzymes of threonine oxidation. Threonine dehydrogenase (TDH) converts threonine to 3-keto, 2-amino propionic acid which is subsequently converted by 2-amino-3-ketobutyrate coenzyme A ligase to glycine and acetyl CoA. Serine and threonine are substrates for serine-threonine dehydratase (SDH) which deaminates both to yield 2-oxo-butyric acid.

leads to changes in the circulating levels of amino acids late in pregnancy. In particular there are large changes in the steady state concentrations of L-threonine. By day 21 of gestation the L-threonine concentration in the serum of dams fed the diet containing $9 \%$ protein was less than half of that found in animals fed the diet containing $18 \%$ protein. This was accompanied by a corresponding decrease in concentrations of free L-threonine in the foetuses [2]. The mechanism underlying this sensitivity of threonine concentrations to protein intake during gestation is unknown.

The rat has two metabolic pathways for the catabolism of threonine (Fig. 1). The first pathway involves the deamination of threonine by the enzyme serine-threonine dehydratase (EC 4.2.1.16: SDH) to yield 2-oxo butyric acid which is subsequently oxidised to $\mathrm{CO}_{2}$. SDH is primarily expressed in the liver and kidney although it is present at lower levels in other tissues [3]. Hepatic SDH activity is determined by the protein content of the diet and increases when protein intake exceeds the requirements [4]. The second pathway for threonine catabolism proceeds through the enzyme L-threonine 3-dehydrogenase (EC 1.1.1.103; TDH). This enzyme converts threonine to 2-amino 3-oxo butyrate, which is subsequently cleaved to yield glycine and acetyl-CoA. The enzymes of this pathway are widely expressed in a number of different tissues [5]. The relative importance of these two pathways during pregnancy and the role that they play in determining plasma threonine concentrations is unknown. In this study we investigated the effects of dietary protein intake on the activities of threonine dehydrogenase and serine-threonine dehydratase in the pregnant rat.

\section{METHODS}

\subsection{Experimental diets}

The experimental diets were similar to those described previously [6]. The $18 \%$ 
protein diet contained $\left(\mathrm{g} \cdot \mathrm{kg}^{-1}\right)$ casein, 180; sucrose, 213; cellulose fibre (solkaflok) 50; corn starch, 425; vitamin mix AIN76 (ICN Ltd), 5; mineral mix AIN-76 (ICN Ltd), 20; corn oil, 100; choline chloride, 2 . The $9 \%$ protein diet contained $90 \mathrm{~g} \cdot \mathrm{kg}^{-1}$ casein, with compensating increases in the amounts of sucrose and corn starch (1:3). Both diets were supplemented with $0.5 \% \mathrm{w} / \mathrm{w}$ DL-methionine. Choline chloride and methionine were from Sigma (Poole, Dorset, UK), the other ingredients were from Special Diet Services (Witham, Essex, UK).

\subsection{Experimental animals}

Female rats of the Rowett Hooded Lister strain from The Institute's breeding colony were fed the experimental diets ad libitum commencing at 6-7 weeks of age. The diets were fed for a two-week period to allow the animals to adapt to the diets. At the end of this period one group of animals was killed to provide baseline samples. The remaining animals, which weighed approximately 230-280 g, were mated with males of the same strain. Mating was confirmed by detection of a vaginal plug and this was denoted day 0 . The female rats were maintained on the same diets throughout pregnancy. At intervals throughout gestation, the dams were killed by stunning and exsaguination, the foetuses were rapidly removed, weighed and killed by decapitation. Maternal tissues were removed, washed in saline, blotted dry and weighed. One portion of the maternal liver was homogenised immediately and used for the estimation of threonine oxidation by the method described previously [7]. The remainder of the maternal liver and samples of other tissues was divided into portions, frozen in liquid nitrogen and then stored at $-70{ }^{\circ} \mathrm{C}$ until required. Some samples at $\mathrm{d} 21$ of gestation were derived from animals used in a previous study which followed a similar protocol [7]. All experimental procedures were approved and conducted in accordance with the UK Animals (Scientific Procedures) Act, 1986.

\subsection{Amino acid analysis}

Serum samples were analysed with a Waters Pico-Tag system (Waters Corp., Milford, MA, USA). Phenylisothiocyanate derivatives were separated on a C18 column using a $70 \mathrm{mM}$ gradient of sodium acetate-acetonitrile buffer ( $\mathrm{pH}$ 6.46) and detected by u.v. absorption at $254 \mathrm{~nm}$. The chromatograms were analysed using the Waters Millennium software package (Waters Corp.).

\subsection{Threonine dehydrogenase assay}

Threonine dehydrogenase was assayed by the method of Davis and Austic [8]. Briefly, a portion of tissue was homogenised in 2 volumes of buffer (0.14M KCl, $0.25 \%$ Triton X-100) using a Glass/Teflon homogeniser and filtered through $0.25 \mu$ nylon mesh. The assay was carried out in a $1.0 \mathrm{~mL}$ volume containing $25 \mathrm{mM}$ Tris ( $\mathrm{pH} 8.2), 100 \mathrm{mM}$ L-threonine, $0.5 \mathrm{mM}$ NAD and $0.15 \mathrm{~mL}$ homogenate. After $30 \mathrm{~min}$ at $37{ }^{\circ} \mathrm{C}$ the reaction was terminated by the addition of $0.5 \mathrm{~mL} 35 \%$ TCA. After centrifugation $0.5 \mathrm{~mL}$ of supernatant was transferred to a glass tube and $0.5 \mathrm{~mL} 1 \mathrm{M}$ Sodium Acetate, $50 \mu \mathrm{L} 2.5 \mathrm{M} \mathrm{NaOH}$ and $25 \mu \mathrm{L}$ of acetylacetone was added. The reaction mixture was heated at $100{ }^{\circ} \mathrm{C}$ for $10 \mathrm{~min}$, cooled prior to the addition of $1 \mathrm{~mL}$ of Erlichs Reagent (1\% dimethyl amino benzamide dissolved in glacial acetic acid containing $10 \%$ PCA). The sample was allowed to stand for $10 \mathrm{~min}$ at room temperature before the absorbance of the sample at $553 \mathrm{~nm}$ was determined. Colour development was dependent on the addition of NAD and threonine to the enzyme 
a.

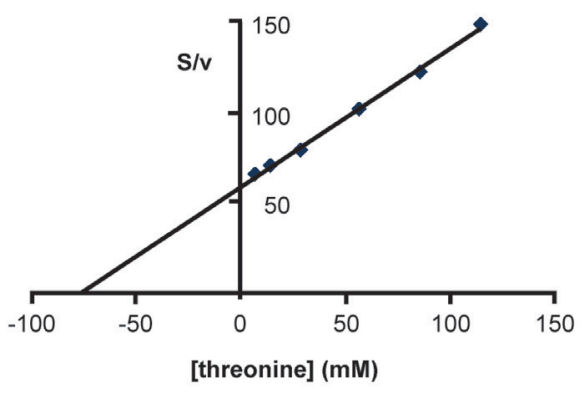

b.

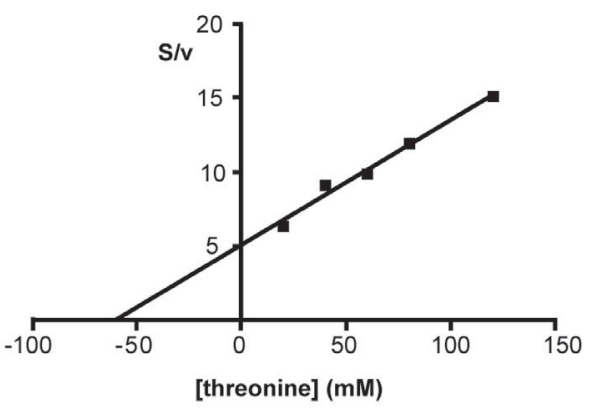

c.

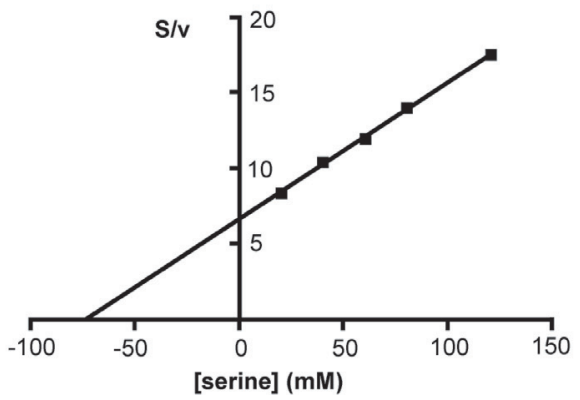

Figure 2. Kinetics of TDH and SDH. The activity was determined in preparations from the livers of non-pregnant female rats. Rates were calculated from the linear portion of the progress curve and the lines fitted by linear regression. (a) Threonine dehydrogenase activity, $\mathrm{Km}=$ $82 \mathrm{mM}$. (b) Serine-threonine dehydratase using threonine as substrate, $\mathrm{Km}=60.27 \mathrm{mM}$ and $\mathrm{Vmax}=11.86 \mathrm{nmol} / \mathrm{min} / \mathrm{mg}$ protein; and (c) serine-threonine dehydratase using serine as substrate, $\mathrm{Km}=72.4 \mathrm{mM}$. assay mixture. Enzyme extracts from stock fed non-pregnant animals showed the $\mathrm{Km}$ for threonine was $82 \mathrm{mM}$ and the $V \max$ was $1.3 \mathrm{nmol}$ threonine $/ \mathrm{min} / \mathrm{mg}$ protein (Fig. 2a).

\subsection{Serine-threonine dehydratase assay}

Serine-threonine dehydratase was assayed by the method of Ogawa [9]. Briefly, a portion of tissue was homogenised in 2 volumes of buffer $(0.15 \mathrm{M} \mathrm{KCl}, 0.1 \mathrm{M}$ Tris (pH 7.4) and $1 \mathrm{mM}$ EDTA) and centrifuged at $100000 \times g$ for $15 \mathrm{~min}$. Liver homogenates from control and protein deficient animals yielded approximately equivalent quantities of soluble cytosolic proteins $\left(108.6 \pm 3.6 \mathrm{mg} \cdot \mathrm{g}^{-1}\right.$ tissue and $105.9 \pm 7.9 \mathrm{mg} \cdot \mathrm{g}^{-1}$ tissue for $18 \%$ protein and $9 \%$ protein respectively). The assay was carried out in a 96 well microtitre plate with $12.5 \mu \mathrm{L}$ of buffer $(0.2 \mathrm{M}$ sodium borate, $1 \mathrm{mM}$ pyridoxal phosphate $(\mathrm{pH} 8.3)$ and $7.5 \mu \mathrm{L}$ of enzyme extract in each well. The plate was pre-warmed to $37{ }^{\circ} \mathrm{C}$ for $10 \mathrm{~min}$ before the reaction was started by the addition of $20 \mu \mathrm{L} 0.2 \mathrm{M} \mathrm{L}$ serine. After $10 \mathrm{~min}$ at $37^{\circ} \mathrm{C}$ the reaction was terminated by the addition of $40 \mu \mathrm{L}$ dinitrophenyl hydrazine reagent $(0.165 \%$ $(\mathrm{w} / \mathrm{w})$ in $2 \mathrm{M} \mathrm{HCl})$. After $5 \mathrm{~min}$ at room temperature $160 \mu \mathrm{L}$ of $2 \mathrm{M} \mathrm{NaOH}$ was added and after a further $5 \mathrm{~min}$ at room temperature the absorbance at $540 \mathrm{~nm}$ was determined. Enzyme extracts from stock fed non-pregnant animals showed that $\mathrm{SDH}$ had a $\mathrm{Km}=60 \mathrm{mM}$ and $\mathrm{Vmax}=$ $11.9 \mathrm{nmol} / \mathrm{min} / \mathrm{mg}$ protein using threonine as substrate (Fig. 2b) and a $\mathrm{Km}$ of $72 \mathrm{mM}$ and a $\mathrm{Vmax}$ of $11.0 \mathrm{nmol} / \mathrm{min} / \mathrm{mg}$ protein using serine as substrate (Fig. 2c).

\subsection{Statistics}

All data were analysed using the Genstat 6 statistical package (Genstat 6, Lawes 
Table I. Changes in the maternal liver during pregnancy.

\begin{tabular}{lccrrr}
\hline Diet & Day of gestation & Non-pregnant & \multicolumn{1}{c}{ Day 4 } & \multicolumn{1}{c}{ Day 11 } & Day 19 \\
\hline $18 \%$ protein & Body weight $(\mathrm{g})$ & $236.3 \pm 2.3$ & $297.7 \pm 35.7$ & $338.5 \pm 7.8$ & $345.5 \pm 29.3$ \\
& Liver weight $(\mathrm{g})$ & $10.29 \pm 1.12$ & $11.57 \pm 1.65$ & $12.35 \pm 0.22$ & $13.58 \pm 0.50$ \\
& Liver $(\%$ of body weight) & $4.35 \pm 0.46$ & $4.03 \pm 0.29$ & $3.65 \pm 0.02$ & $3.78 \pm 0.12$ \\
\multirow{3}{*}{ \% protein } & Body weight $(\mathrm{g})$ & $233.7 \pm 4.7$ & $282.3 \pm 34.9$ & $317.3 \pm 27.3$ & $364.2 \pm 13.3$ \\
& Liver weight $(\mathrm{g})$ & $8.53 \pm 0.57 *$ & $11.13 \pm 1.30$ & $13.39 \pm 0.86$ & $14.16 \pm 0.25$ \\
& Liver $(\%$ of body weight) & $3.65 \pm 0.22$ & $3.95 \pm 0.22$ & $4.30 \pm 0.18$ & $3.89 \pm 0.08$ \\
\hline
\end{tabular}

Changes in the dam during gestation. Values are mean $\pm \operatorname{sd}(n=4), * P<0.05$.

Agricultural Trust, Rothamsted Experimental Station, Harpenden, Herts, UK). All data are presented as mean \pm SD. Amino acid concentrations at each time point were analysed by an unpaired Student $t$-test. The same data were also analysed by 2-way ANOVA to test for diet $x$ time interactions. Enzyme activities were assessed by an unpaired Student $t$-test at each individual time point.

\section{RESULTS}

The growth of the animals fed diets containing $18 \%$ and $9 \%$ protein was similar to experiments reported previously [2]. The protein content of the maternal diet had no significant effect on the feed intakes and did not affect the growth of the animals, before or after mating (data not shown). The protein content of the maternal diet had no effect on the weight of the gravid uterus, which weighed $35.5 \pm 14.4 \mathrm{~g}$ on day 19 of gestation in the group fed the $18 \%$ protein diet compared with $41.9 \pm$ $13.5 \mathrm{~g}$ from the dams fed the $9 \%$ protein diet. Dams fed $18 \%$ protein had an average of $10.3 \pm 4.5$ foetuses/dam and this litter size was not significantly different from the dams fed $9 \%$ protein with an average of $13.2 \pm 4.8$ foetuses/dam. During the course of pregnancy, the maternal liver increased in weight as shown in Table I. In the group of animals fed the diet containing $18 \%$ protein, liver weight increased by approximately $30 \%$ by day 19 of gestation. Before mating, the livers from the non-pregnant animals fed the diet containing $9 \%$ protein were significantly smaller than the livers taken from the group fed $18 \%$ protein. However, there was a rapid increase in liver weight once the animals in this group were mated and thereafter there was no significant difference between the liver weights of the two groups. The liver weight of the animals fed the diet containing $9 \%$ protein increased by approximately $66 \%$ by day 19 of gestation. When the liver weights are expressed as a percentage of the body weight there were no significant differences between the two diet groups.

Amino acid profiles from the maternal serum of animals killed at different times during gestation are shown in Table II. Reducing the protein content of the diet reduced the concentration of glutamine and increased the concentrations of threonine in the serum of non-pregnant animals. Threonine concentrations were $54 \%$ higher $(P=0.018)$ in the non-pregnant animals fed the $9 \%$ protein diet when compared to the control group fed the $18 \%$ protein diet.

There was also an effect of the branched chain amino acids on the concentrations. The sum of the branched chain amino acid concentrations in the dams fed the diet containing $9 \%$ protein were approximately $65 \%$ of the value, found in the group fed the diet containing $18 \%$ protein $(P=0.019)$. 


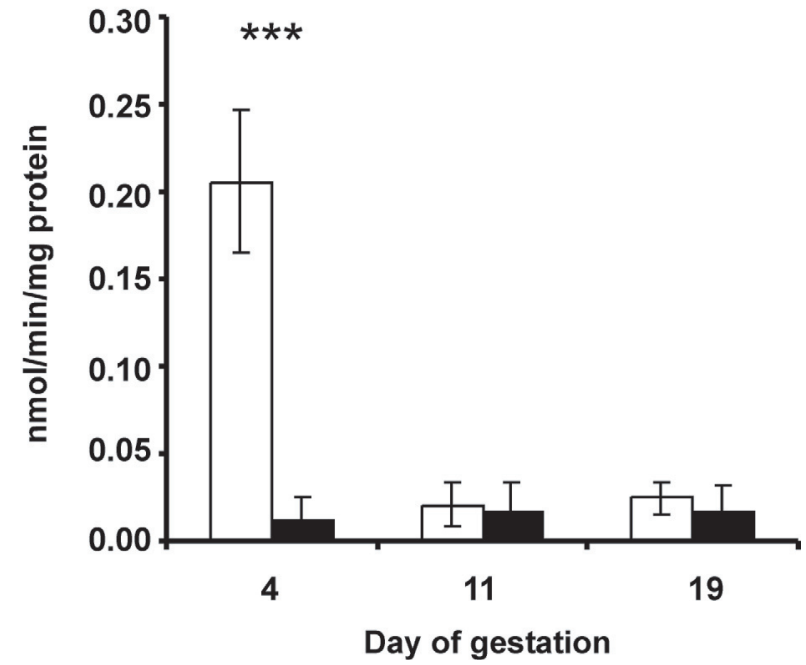

Figure 3. Threonine oxidation. Threonine oxidation by homogenates of liver prepared from dams at different stages of gestation. The open bars represent the animals fed the diet containing $18 \%$ protein and the closed bars the animals fed the diet containing $9 \%$ protein. Rates were determined from the initial linear portions of the progress curves. Error bars $=\mathrm{sd}$ $(n=4)$.
The changes in amino acid concentrations were analysed by two-way ANOVA to identify the effects of time, the protein content of the maternal diet and the interactions between these two factors. Total amino acid concentrations were significantly changed during the course of pregnancy $(P<0.001)$ however, there was no significant effect of the diet (protein content) or any interaction between the protein content of the diet and stage of pregnancy. The concentrations of free amino acids in the maternal serum fell significantly as pregnancy progressed and this affected all of the amino acids $(P<0.001)$. The maternal diet containing $9 \%$ protein significantly reduced the concentrations of the branched chain amino acids in the serum of the dam throughout the duration of pregnancy $(P<0.001)$. There were also reductions in the concentrations of serine $(P=$ $0.009)$, histidine $(P=0.004)$, proline $(P=$ $0.015)$, and tyrosine $(P=0.05)$.

Unlike the majority of amino acids, threonine concentrations were subject to a significant interaction between the protein content of the diet and stage of pregnancy $(P<0.05)$. Initially higher in the non-pregnant animals, threonine concen- trations fell rapidly in the animals fed the diet containing $9 \%$ protein and were only $35 \%$ of the values found in the animals fed $18 \%$ protein by day 19 of gestation. $(P=0.001)$. There was also evidence for a weak interaction between the protein content of the maternal diet and the stage of pregnancy influencing the concentrations of the branched chain amino acids (interaction diet $\times$ day $P=0.06$ ). However, while the difference in threonine concentrations increased progressively during the course of gestation, the largest differences in the branched chain amino acids were observed in non-pregnant animals and during the early stages of gestation. Halving the protein content of the diet reduced the branched chain amino acid concentrations to approximately $65 \%$ of the level found in the higher protein group in the nonpregnant animals. However, by day 19 of gestation the concentrations had recovered and were 85 to $90 \%$ of those found in animals fed the diet containing $18 \%$ protein.

The rates of threonine oxidation by liver homogenates prepared from the dams killed at different stages of gestation are shown in Figure 3 . The rates of threonine oxidation by homogenates of liver 

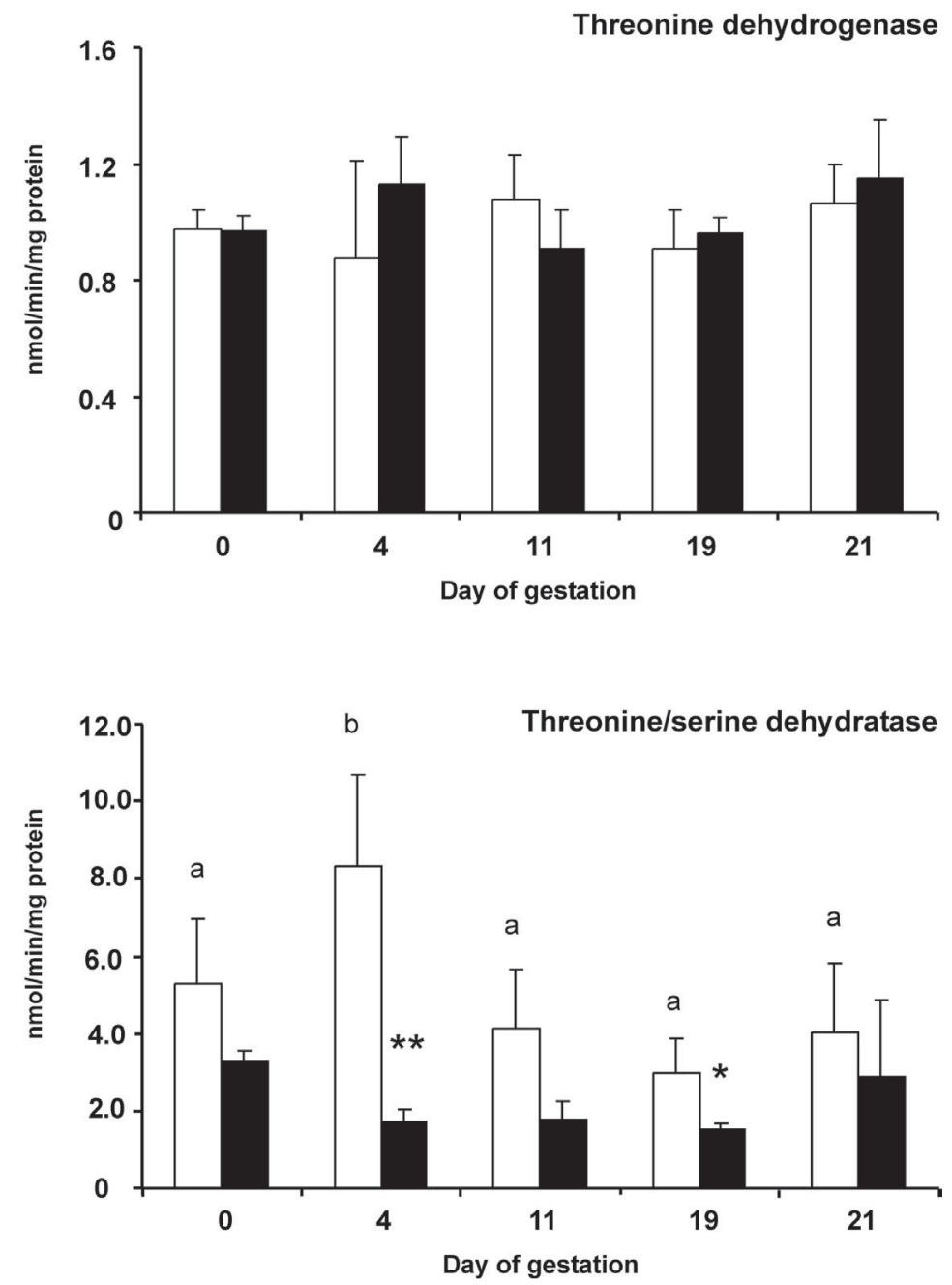

Figure 4. Changes in TDH and SDH activity during pregnancy. Threonine dehydrogenase (a) and serine-threonine dehydratase activity (b) of liver preparations from dams at different stages of gestation. The open bars are preparations from animals fed the diet containing $18 \%$ protein and the closed bars the preparations from animals fed the diet containing 9\% protein. The samples from day 21 were taken from an experiment described previously [7]. Bars sharing a common subscript are not significantly different from one another. ${ }^{*} P<0.05, * * P<0.01$ Error bars $+\operatorname{sd}(n=4)$.

prepared from animals fed the diet containing $18 \%$ protein fell between days 4 and 11 of gestation. In contrast, the rates of threonine oxidation were already low by day 4 in the homogenates of liver prepared from animals fed the diet containing $9 \%$ protein.
Figure 4 shows the specific activity of $\mathrm{TDH}$ and SDH in homogenates prepared from maternal livers at different stages of gestation. The activity of threonine dehydrogenase (upper panel of Fig. 4) remained constant throughout pregnancy and 


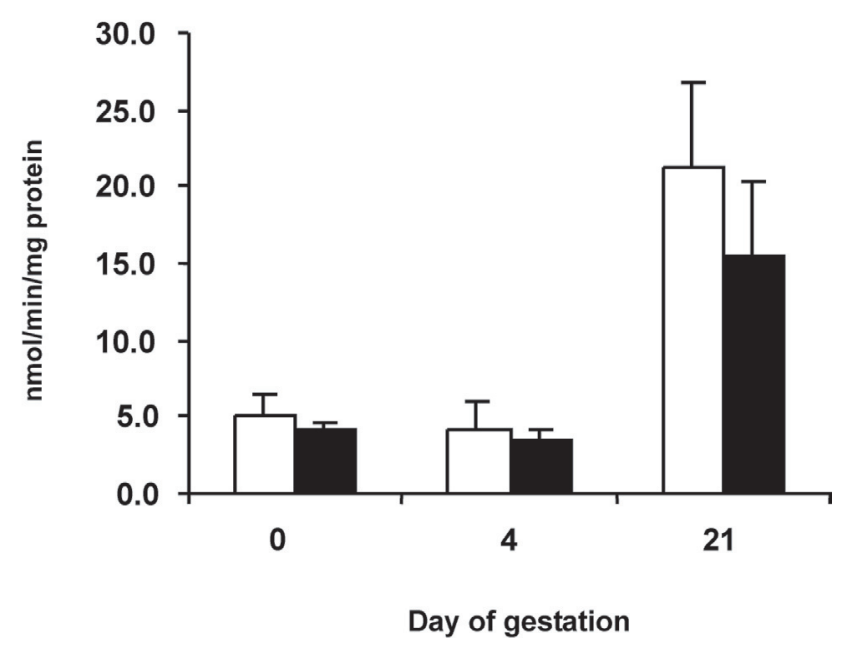

Figure 5. Changes in SDH activity in the kidney during gestation. The open bars are preparations from animals fed the diet containing $18 \%$ protein and the closed bars the preparations from animals fed the diet containing $9 \%$ protein. The samples from day 21 were taken from an experiment described previously [7]. Error bars $+\operatorname{sd}(n=4)$.

was not affected by the protein content of the maternal diet. The activity of serinethreonine dehydratase is shown in the lower panel of Figure 4. In the animals fed a diet containing $18 \%$ protein there was a significant increase in the activity on day 4 of pregnancy, however, this change was transient and the activity later in gestation was not significantly different from that found in the non pregnant liver. This transient increase in activity was not found in the dams fed the diet containing $9 \%$ protein and there were no significant differences in the activity during gestation. As a result, reducing the protein content of the diet led to a significant reduction in SDH activity of the liver on day 4 of pregnancy $(P<0.01)$. This change in activity is not accounted for by the growth of the maternal liver, since the total serine-threonine dehydratase activity is still 4.2 fold higher at day 4 in the dams fed the high protein diet. The overall pattern of activity closely resembled the change in oxidation with the highest rates in liver extracts from the animals fed the $18 \%$ protein diets on day 4 .
The tissue distribution of SDH activity was assessed in homogenates of the heart, kidney, lung, spleen, skeletal muscle, uterus and gut from animals fed $18 \%$ protein on day 19 of gestation. Apart from the liver, the kidney was the only other maternal organ with a significant SDH activity (data not shown). Figure 5 shows that in non-pregnant animals and in the early stages of gestation, the specific activity of SDH in the kidney is comparable to that found in the liver. In the later stages of gestation, the renal SDH activity increased significantly in both animals fed the $18 \%$ and $9 \%$ protein diets. There was no significant effect of the protein content of the maternal diet on renal SDH activity at either the early or late stages of gestation.

It has been reported that the developing placenta expresses SDH, particularly during the early stages of foetal development [10]. The specific activity of SDH in extracts prepared from the placenta at $\mathrm{d} 19$ of gestation was $0.34 \pm 0.05 \mathrm{nmol} / \mathrm{min} / \mathrm{mg}$ protein, or approximately $26 \%$ of the specific activity found in the maternal liver at 
the same stage of gestation. The protein content of the maternal diet did not influence placental SDH activity at day 19 of gestation (data not shown).

\section{DISCUSSION}

These results were in agreement with previous studies which have reported a generalised fall in amino acid concentrations in the maternal serum as gestation progresses [11]. However, a 50\% decrease in the protein content of the diet has surprisingly modest effects on the concentrations of most amino acids. This suggests that the rat has a considerable capacity to adapt to a reduction in the protein supply by mobilisation of body proteins [12]. These changes in protein and fat mobilisation account for the dams of animals fed the low protein diets weighing significantly less after they have given birth compared to the offspring of dams fed a high protein diet [13]. However, in the absence of precise nitrogen balance data it is difficult to determine the optimal dietary protein intake for the rat during gestation and the shift to a diet containing $9 \%$ protein may not cause a significant deficiency at this stage. The higher level of protein (18\%) may only be required at the later, catabolic stage of gestation and during lactation.

In keeping with our previous studies [2], threonine concentrations are influenced by reducing the protein content of the maternal diet. The difference between animals fed diets containing either $18 \%$ protein or $9 \%$ protein becomes progressively greater as gestation proceeds. This change in threonine concentrations throughout gestation contrasts with the effects on concentrations of the branched chain amino acids, where the difference produced by feeding the diet with a lower protein content is the greatest in the non-pregnant animals and during the initial stages of gestation.
The metabolism of branched chain amino acids by skeletal muscle is linked to the production of alanine and glutamine [14]. Changes in the activity of the glucosealanine cycle and in the concentrations of branched chain amino acids are consistent with an adaptation to a reduced nitrogen supply in the non-pregnant animals and in the early stages of gestation. Later in gestation the dietary protein supply plays a smaller role compared to the mobilisation of body protein stores and thus there is a smaller effect on amino acid concentrations. This does not appear to be the case for threonine where body stores appear to be unable to maintain the concentrations in the circulation, suggesting that there is something unusual about the metabolism of this amino acid.

On the basis of measurements made late in gestation (day 21), we had initially hypothesised that the falling concentrations in the circulation were the result of an increase in threonine oxidation [7]. These new data show that hepatic oxidation cannot account for the changes in plasma threonine concentrations. On day 4 of gestation, the rates of threonine oxidation by liver homogenates prepared from livers of animals fed the diet containing $18 \%$ protein were significantly higher than those found in liver homogenates prepared from animals fed the diet containing 9\% protein. However, this change in activity was not reflected in altered amino acid concentrations in the maternal serum. In fact, during the early stages of gestation, the maximal rates of threonine oxidation are lower in the liver of dams fed the low protein diets compared to those fed the high protein diet. At the same time, plasma threonine concentrations are falling faster in the group fed low protein diets compared to those fed the high protein diet.

The change in threonine oxidation would appear to be almost entirely attributable to the SDH activity, since the rate of threonine oxidation correlates well 
with the measured enzyme activity. Although the two enzymes have similar Km values, the maximal activity of TDH is lower than that of SDH. In isolated rat hepatocytes approximately $65 \%$ of threonine oxidation occurs through the threonine dehydratase pathway [15]. A similar situation is found in humans where the TDH pathway accounts for only $7-11 \%$ of total threonine catabolism [16]. The activity of hepatic SDH increases when the intake of protein exceeds protein requirements. Although the enzyme is sensitive to hormones, the activity appears to be determined by combination of factors which reflect total protein intake [17]. The increase in SDH activity during the first days of gestation may indicate that the diet containing $18 \%$ protein provides more protein than is required. The animals fed the diet containing $9 \%$ protein have no excess and the transient increase in hepatic SDH activity may be suppressed in the group fed the diet containing $9 \%$ protein in order to conserve threonine. However, it is also possible to interpret this result as suggesting that the diet containing $18 \%$ protein as recommended by the AIN [18] is providing an excess of protein during the early stages of gestation and the enzyme is induced to deal with this. In the absence of nitrogen balance data we are unable to resolve these two possibilities. SDH activity also changes following a diverse range of treatments including, laparotomy, or the administration of glucagon, dexamethasone or streptozotocin [19]. Therefore the increase in SDH activity may also reflect changes in the endocrine environment during the establishment of pregnancy.

These data suggest that SDH activity is primarily found in the maternal liver. There is a small but increasing contribution from the kidney late in gestation. Kidney SDH is dramatically induced by either glucagon or dexamethasone whereas the liver enzyme is induced by glucagon but not by dexamethasone [20]. Therefore the changes in re- nal SDH activity may be related to the increases in glucocorticoids induced by protein deficiency [6]. The other tissue that may contribute to threonine metabolism is the placenta. However the activity later in gestation is small relative to the maternal liver, suggesting that the placenta plays a reduced role in threonine metabolism in the later stages of gestation.

Changes in free threonine pools and SDH activity have been reported in animals fed experimental diets containing an excess of methionine [21]. We have previously pointed out that the semi-synthetic diets used in these experiments contain an imbalance in the methionine content relative to other amino acids [22]. However, the levels of methionine required to induce SDH activity in non-pregnant animals are much higher than those used here, requiring a methionine supplement of $2-4 \%$ (w/w) to produce a two fold increase in activity in males [23]. In addition, the methionine dependent induction of SDH is transient, with the activity reverting to normal after two weeks. In the present experiments the animals were adapted to the diets over a 2 week period prior to mating, giving time for any transient change in activity to pass. Furthermore, recent studies using diets with a reduced methionine content have shown that there is still a pregnancy dependent decrease in threonine concentrations (W. Rees, unpublished data).

It is clear that threonine metabolism during pregnancy is unusual when compared to other amino acids. These data show that the changes in circulating free pools cannot be accounted for by a change in the oxidation of threonine. The results show that changes in SDH activity induced by changes in dietary protein intake are compatible with the conservation of threonine rather than its oxidation. This suggests that other less conventional routes for threonine metabolism may be creating an increased demand during gestation. One possibility is that threonine is being 
converted to glycine. In humans, the TDH pathway accounts for only $7-11 \%$ of threonine oxidation [16] in adults whereas up to $44 \%$ of oxidation is through this pathway in preterm infants [24]. Glycine is also important during gestation in rodents [25] and even a small increase in the conversion of threonine to glycine may lead to a considerable increase in the demand because of the high glycine flux. However in a preliminary experiment where animals were infused with $\left[\mathrm{U}_{-}{ }^{14} \mathrm{C}\right]$ threonine on d21 of gestation, we were unable to detect any radioactivity in serum or intracellular glycine pools (Rees and Palmer unpublished results). Threonine is a gluconeogenic amino acid and therefore it may be being converted to glucose to meet the increased demands of gestation. However, the experimental diets contain a significant amount of simple sugars (21-24\% w/w sucrose fed ad libitum), which makes it unlikely that the animals were energy restricted. Furthermore, it has been reported that the rate of gluconeogenesis from threonine by the rat liver is disproportionately low when concentrations are low, effectively limiting the utilisation of threonine when it is in short supply [26]. Recent studies have also presented evidence that the gut has a very high requirement for threonine [27] and it is possible that an increase in the production of gastric mucins may increase the requirement for threonine during gestation.

The pregnant rat subjected to a modest protein deficiency has become widely used as an animal model in the study of metabolic programming [28] since this seemingly mild intervention produces long lasting changes in the offspring, including reduced glucose tolerance, defects in insulin secretion and raised blood pressure. $[25,29-31]$. It is becoming clear that a disturbance in maternal metabolism lies at the centre of these changes and a perturbation of amino acid metabolism may be an important mechanism.

\section{ACKNOWLEDGEMENTS}

This work was supported by the Scottish Executive, Environment and Rural Affairs Department as part of the Rowett Research Institute core funding. We wish to express our thanks to K. Simpson D. Wallace and V. Buchan for their skilled technical assistance. We are grateful to Dr H. Ogawa (Toyama Medical and Pharmaceutical University, Toyama Japan) for assistance with the SDH assay.

\section{REFERENCES}

[1] Naismith DJ, Morgan BL. The biphasic nature of protein metabolism during pregnancy in the rat. Br J Nutr 1976, 36: 563-566.

[2] Rees WD, Hay SM, Buchan V, Antipatis C, Palmer RM. The effects of maternal protein restriction on the growth of the rat fetus and its amino acid supply. Br J Nutr 1999, 81: 243-250.

[3] Su Y, Kanamoto R, Miller DA, Ogawa H, Pitot HC. Regulation of the expression of the serine dehydratase gene in the kidney and liver of the rat. Biochem Biophys Res Commun 1990, 170: 892-899.

[4] Ogawa H, Fujioka M, Su Y, Kanamoto R, Pitot HC. Nutritional regulation and tissuespecific expression of the serine dehydratase gene in rat. J Biol Chem 1991, 266: 2041220417.

[5] Edgar AJ. Molecular cloning and tissue distribution of mammalian L-threonine 3dehydrogenases. BMC Biochem 2002, 3: 19.

[6] Langley-Evans SC, Gardner DS, Jackson AA. Maternal protein restriction influences the programming of the rat hypothalamicpituitary-adrenal axis. J Nutr 1996, 126: $1578-1585$.

[7] Rees WD, Hay SM, Brown DS, Antipatis C, Palmer RM. Maternal protein deficiency causes hypermethylation of DNA in the livers of rat fetuses. J Nutr 2000, 130: 18211826.

[8] Davis AT, Austic RE. Threonine-degrading enzymes in the chicken. Poult Sci 1982, 61: 2107-2111.

[9] Ogawa H, Kawamata S, Gomi T, Ansai Y, Karaki Y. Laparotomy causes a transient induction of rat liver serine dehydratase mRNA. Arch Biochem Biophys 1995, 316: 844-850.

[10] Remesar X, Arola L, Palou A, Alemany M. Activities of enzymes involved in aminoacid metabolism in developing rat placenta. Eur J Biochem 1980, 110: 289-293. 
[11] Palou A, Arola L, Alemany M. Plasma amino acid concentrations in pregnant rats and in 21-day foetuses. Biochem J 1997, 166: 49-55.

[12] Ling PR, Bistrian BR, Blackburn GL, Istfan N. Effect of fetal growth on maternal protein metabolism in postabsorptive rat. Am J Physiol 1987, 252: E380-E390.

[13] Rees WD, Hay SM, Cruickshand M, Reusens B, Remacle C, Antipatis C, Grant G. Maternal protein intake in the pregnant rat programmes the insulin axis and body composition in the offspring. Metab Clin Exp 2006, 55: 641-648.

[14] Harper AE, Miller RH, Block KP. Branchedchain amino acid metabolism. Annu Rev Nutr 1984, 4: 409-454.

[15] House JD, Hall BN, Brosnan JT. Threonine metabolism in isolated rat hepatocytes. Am J Physiol Endocrinol Metab 2001, 281: E1300-E1307.

[16] Darling PB, Grunow J, Rafii M, Brookes S, Ball RO, Pencharz PB. Threonine dehydrogenase is a minor degradative pathway of threonine catabolism in adult humans. Am J Physiol Endocrinol Metab 2000, 278: E877E884.

[17] Kanamoto R, Su Y, Pitot HC. Hormonal regulation of serine dehydratase gene expression in liver and kidney of the adrenalectomized rat. Mol Endocrinol 1991, 5: 16611668.

[18] Reeves PG. Components of the AIN-93 diets as improvements in the AIN-76A diet. J Nutr 1997, 127: 838S-841S.

[19] Ogawa H, Kawamata S. Periportal expression of the serine dehydratase gene in rat liver. Histochem J 1995, 27: 380-387.

[20] Su Y, Kanamoto R, Miller DA, Ogawa H, Pitot HC. Regulation of the expression of the serine dehydratase gene in the kidney and liver of the rat. Biochem Biophys Res Commun 1990, 170: 892-899.

[21] Girard-Globa A, Robin P, Forestier M. Longterm adaptation of weanling rats to high dietary levels of methionine and serine. J Nutr 1972, 102: 209-217.
[22] Petrie L, Duthie SJ., Rees WD, McConnell JM. Serum concentrations of homocysteine are elevated during early pregnancy in rodent models of fetal programming. Br J Nutr 2002, 88: 471-477.

[23] Sanchez A, Swendseid ME, Clark AJ, Umezawa C. Amino acid pools and hepatic enzyme activities in rats fed a meal of high or low methionine content. Am J Clin Nutr 1972, 25: 550-554.

[24] Darling PB, Dunn M, Sarwar G, Brookes S, Ball RO, Pencharz PB. Threonine kinetics in preterm infants fed their mothers' milk or formula with various ratios of whey to casein. Am J Clin Nutr 1999, 69: 105-114.

[25] Brawley L, Torrens C, Anthony FW, Itoh S, Wheeler T, Jackson AA, Clough GF, Poston L, Hanson MA. Glycine rectifies vascular dysfunction induced by dietary protein imbalance during pregnancy. J Physiol 2004, 554: 497-504.

[26] Bloxam DL. Restriction of hepatic gluconeogenesis and ureogenesis from threonine when at low concentrations. Am J Physiol 1975, 229: 1718-1723.

[27] Schaart MW, Schierbeek H, van der Schoor Sr, Stoll B, Burrin DG, Reeds PJ, van Goudoever JB. Threonine utilization is high in the intestine of piglets. J Nutr 2005, 135: 765-770.

[28] Armitage JA, Khan IY, Taylor PD, Nathanielsz PW, Poston L. Developmental programming of the metabolic syndrome by maternal nutritional imbalance: how strong is the evidence from experimental models in mammals? J Physiol 2004, 561: 355-377.

[29] Desai M, Crowther NJ, Ozanne SE, Lucas A, Hales CN. Adult glucose and lipid metabolism may be programmed during fetal life. Biochem Soc Trans 1995, 23: 331-335.

[30] Desai M, Byrne CD, Zhang J, Petry CJ, Lucas A, Hales CN. Programming of hepatic insulin-sensitive enzymes in offspring of rat dams fed a protein-restricted diet. Am J Physiol 1997, 272: G1083-G1090.

[31] Langley SC, Jackson AA. Increased systolic blood pressure in adult rats induced by fetal exposure to maternal low protein diets. Clin Sci 1994, (Lond) 86: 217-222. 